\title{
Cytotoxicity of Latex and Non-Latex Orthodontic Elastomeric Ligatures on L929 Mouse Fibroblasts
}

\author{
Rogério Lacerda dos SANTOS ${ }^{1}$ \\ Matheus Melo PITHON ${ }^{1}$ \\ Fernanda Otaviano MARTINS ${ }^{2}$ \\ Maria Teresa Villela ROMANOS ${ }^{2}$ \\ Antônio Carlos de Oliveira RUELLAS ${ }^{1}$ \\ ${ }^{1}$ Departament of Orthodontics, Federal University of Rio de Janeiro, Rio de Janeiro, RJ, Brazil \\ ${ }^{2}$ Departament of Microbiology, Federal University of Rio de Janeiro, Rio de Janeiro, RJ, Brazil
}

\begin{abstract}
This study investigated the cytotoxicity exists between latex and non-latex Orthodontic elastomeric ligatures. Six elastomeric ligatures (1 latex, 2 latex-free and 3 polyurethane) from different manufacturers were divided into 6 groups of 15 elastics each: A (Latex-free, American Orthodontics), M (Polyurethane, Morelli), G (Polyurethane,GAC International), Te (Polyurethane, Tecnident), TP (Natural latex,TP Orthodontics) and U (Latex-free,3M Unitek). The cytotoxicity assay was performed using cell cultures (L929 mouse fibroblast cell line), which were subjected to the cell viability test with neutral red ("dye-uptake") at 1, 2, 3, 7 and 28 days. Data were analyzed statistically by ANOVA and Tukey's test $(\alpha=0.05)$. No statistically significant differences $(p>0.05)$ were observed between Groups $\mathrm{M}$ and Te in all experimental periods, except at 2 days. No significant differences $(\mathrm{p}>0.05)$ in cell viability were found either among Groups A, G, TP and U or between Groups M and Te at $24 \mathrm{~h}$ or among Groups CC, A, G, TP and U at 2 and 28 days. It may be concluded that latex-free elastomeric ligatures from American Orthodontics and Unitek trademarks induced less cell lysis compared to latex and polyurethane ligatures.
\end{abstract}

Key Words: cytotoxicity, elastics, biocompatibility, orthodontics.

\section{INTRODUCTION}

Latex elastics are commonly used in orthodontic treatment. However, the protein content of latex is a known allergen. Allergy caused by latex proteins has been well documented (1), including immediate hypersensitivity reactions (2). Amongst the allergic reactions caused by orthodontic elastics, swelling and stomatitis, erythematous oral lesions, respiratory reactions, and even anaphylactic shock, the most severe form of allergy (3), can be cited. Latex allergy occurs in $3-17 \%$ of the cases (4). Because latex allergy is prevalent among occupationally exposed groups and patients, the need for non-latex alternatives is increasing.

However, little is known if latex and non-latex products are cytotoxic to oral mucosal cells (1-6). Cell lines (7), such as L929 mouse fibroblasts (8), have been shown to behave similarly to primary human gingival fibroblasts and are thus a suitable in vitro model to test the toxicity of products used intra-orally during orthodontic treatment (9-11). Considering the hypothesis that differences in cytotoxicity exist between latex and non-latex elastics, the aim of this in vitro study was to evaluate the cytotoxicity of latex and non-latex orthodontic elastomeric ligatures of different manufacturers.

\section{MATERIAL AND METHODS}

Silver-colored orthodontic elastomeric ligatures (modular) from 6 different manufacturers were selected for the cytotoxicity study, being one of natural latex, 2 of latex-free and 3 containing polyurethane (Table 1). The samples were divided into 6 groups of 15 elastics each: Group A (latex-free elastomeric ligatures; American Orthodontics, Sheboygan, WI, USA), Group M (polyurethane elastomeric ligatures; Morelli, Sorocaba, SP, Brazil), Group G (polyurethane

Correspondence: Prof. Dr. Antônio Carlos de Oliveira Ruellas, Programa de Pós-Graduação em Odontologia (Ortodontia), Faculdade de Odontologia, Universidade Federal do Rio de Janeiro, Avenida Prof. Rodolpho Paulo Rocco, 325, Ilha Fundão, 21941-617 Rio de Janeiro, RJ, Brasil. Tel: +5521-2590-2727. e-mail: antonioruellas@yahoo.com.br ou lacerdaorto@hotmail.com 
elastomeric ligatures; GAC International, Bohemia, NY, USA), Group Te (polyurethane elastomeric ligatures; Tecnident, São Carlos, SP, Brazil), Group TP (natural latex elastomeric ligatures; TP Orthodontics, Lodi, CA, USA) and U (latex-free elastomeric ligatures; $3 \mathrm{MUnitek}$, Monrovia, CA, USA) (Fig. 1). All samples had recent manufacturing dates, were from the same production lot, and came in sealed plastic packages. The powder coating of the elastomeric ligatures was removed. The elastics were washed for $15 \mathrm{~s}$ with deionized water by using a Milli-Q purification system (Millipore, Bedford, MA, USA). Before testing all elastomeric ligatures were sterilized by exposure to ultraviolet light (Labconco, Kansas, MO, USA) for $30 \mathrm{~min}(12,13)$.

The cell culture model used was the monolayer containing L929 mouse fibroblast cells (American Type Culture Collection - ATCC, Rockville, MD, USA) was maintained in Eagles' minimum essential medium (Cultilab, Campinas, SP, Brazil) by adding $0.03 \mathrm{mg} /$ $\mathrm{mL}$ of glutamine, $50 \mu \mathrm{g} / \mathrm{mL}$ of garamicine, $2.5 \mathrm{mg} / \mathrm{mL}$ of fungizone, $0.25 \%$ sodium bicarbonate solution, 10 $\mathrm{mM}$ of HEPES, and $10 \%$ fetal bovine serum for growth medium. Next, the cell culture medium was incubated at $37^{\circ} \mathrm{C}$ for $48 \mathrm{~h}$.

To verify the cell response in extreme situations, 3 additional groups were included in the study:

Table 1. Experimental and control groups used for the cytotoxic assays.

\begin{tabular}{lcccc}
\hline Groups & Trademark & $\begin{array}{c}\text { Main } \\
\text { composition }\end{array}$ & Color & $\begin{array}{c}\text { Reference } \\
\text { number }\end{array}$ \\
\hline A & $\begin{array}{c}\text { American } \\
\text { Orthodontics }\end{array}$ & Latex-free & Silver & 854-262 \\
M & Morelli & Polyurethane & Silver & 60-06-117 \\
G & GAC & Polyurethane & Silver & 59-700-14 \\
Te & Tecnident & Polyurethane & Silver & AI-001 \\
TP & TP & Natural latex & Silver & 383-934 \\
Orthodontics & Latex-free & Silver & 406-884 \\
U & Unitek & Tween 80 (polyoxyethylene-20-sorbitan) \\
C+ & \multicolumn{4}{c}{ PBS solution (phosphate-buffered saline } \\
\hline
\end{tabular}

Group CC (cell control), consisting of L929 cells not exposed to supernatants from the elastomeric ligatures; Group C+ (positive control), consisting of Tween 80 (Polyoxyethylene-20-sorbitan; Sigma, St. Louis, MO, USA); Group C- (negative control), consisting of phosphate-buffered saline (PBS) solution (Table 1). The positive and negative controls were incubated in Eagles' minimum essential medium (MEM) for 1, 2, 3, 7 and 28 days and the extracted elutes were added to L929 cells incubated in the growth medium.

The cytotoxicity of these orthodontic elastics was determined through the dye-uptake technique (14), which is based on the neutral red absorption by living cells. These elastomeric ligatures are usually maintained in the oral cavity for up to 4 weeks, since patients wearing fixed appliances usually visit the orthodontist once a month. Different periods of time were considered: 1,2 , 3,7 , and 28 days. These experimental periods represent the time maintenance under cell culture conditions before removal of the elastomeric ligatures.

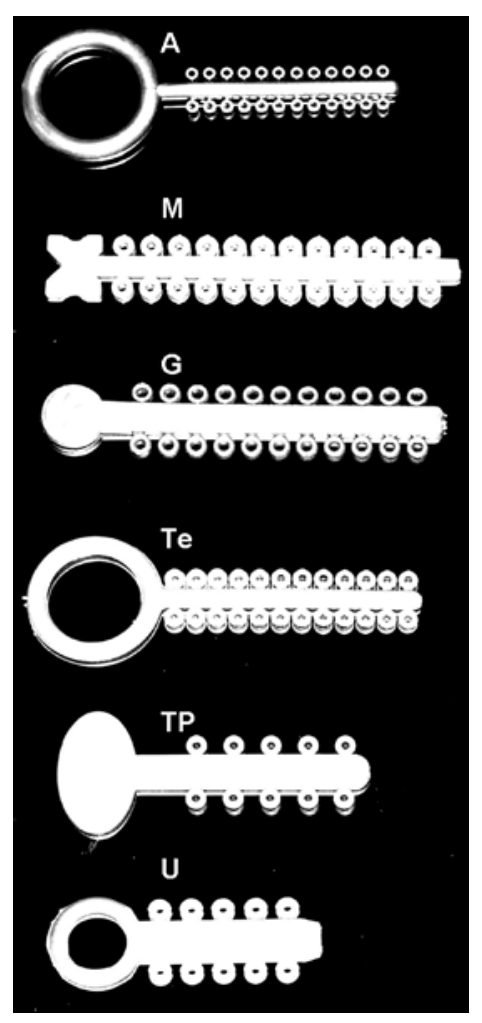

Figure 1. Orthodontic elastomeric ligatures evaluated in this study: A (American Orthodontics), M (Morelli), G (GAC), Te (Tecnident), TP (TP Orthodontics) and U (Unitek). 


\section{Dye-Uptake}

Aliquots of $100 \mu \mathrm{L}$ of L929 cells were distributed into 96-well microplates. After $48 \mathrm{~h}$, the growth medium was replaced with $100 \mu \mathrm{L}$ of MEM obtained following incubation in the different types of elastomeric ligatures at 1, 2, 3, 7 and 28 days. MEM was employed because it is the same type of material used for cell maintenance, thus not influencing the results.

After $24 \mathrm{~h}$ incubation, $100 \mu \mathrm{L}$ of $0.01 \%$ neutral red dye (Sigma) was added to each well in the microplates and incubated for $3 \mathrm{~h}$ at $37^{\circ} \mathrm{C}$. Following this period of time, $100 \mu \mathrm{L}$ of $4 \%$ formaldehyde solution in PBS (130 mmol of NaCl; $2 \mathrm{mmol}$ of KCl; $6 \mathrm{mmol}$ of $\mathrm{Na}_{2} \mathrm{HPO}_{4}$ $2 \mathrm{H}_{2} \mathrm{O} ; 1 \mathrm{mmol}$ of $\mathrm{K}_{2} \mathrm{HPO}_{4} 1 \mathrm{mmol} ; \mathrm{pH}$ 7.2) were added to each well to promote cell attachment to the plate. After $5 \mathrm{~min}, 100 \mu \mathrm{L}$ of $1 \%$ acetic acid and $50 \%$ methanol were added in order to remove the dye not taken up by the cells. After $20 \mathrm{~min}$, a spectrophotometer (BioTek, Winooski, VT, USA) set at a wavelength of
$492 \mathrm{~nm}$ was used to determine the dye taken up by the cells. This test was repeated 3 times, and each test used samples of the media obtained by incubating 15 new elastomeric ligatures from each group for 1, 2, 3, 7 and 28 days. Because elastomeric ligatures can be in the oral cavity for up to 4 weeks, cell viability was determined after exposure to MEM in which the elastics had been incubated for 1, 2, 3, 7 and 28 days.

Data were compared by ANOVA and Tukey's multiple-comparison test was used for identifying differences between the groups. The significance level was set at $\mathrm{p}<0.05$.

\section{RESULTS}

There were no statistically significant differences $(\mathrm{p}>0.05)$ in cell viability among Groups CC, A, G, TP and $\mathrm{U}$ at 2 and 28 days or among Groups CC, A, TP and $U$ at 7 days or between Groups $C C$ and $U$ at 3 days. Nor were there any statistically significant differences

Table 2. The optical density (OD) data and percentage of viable cells (VC) for each group of elastomeric ligatures at 1 to 28 days.

\begin{tabular}{|c|c|c|c|c|c|c|c|c|c|c|}
\hline \multirow[b]{2}{*}{ Group } & \multicolumn{2}{|c|}{1 day } & \multicolumn{2}{|c|}{2 days } & \multicolumn{2}{|c|}{3 days } & \multicolumn{2}{|c|}{7 days } & \multicolumn{2}{|c|}{28 days } \\
\hline & OD & $\begin{array}{l}\mathrm{VC} \\
(\%)\end{array}$ & OD & $\begin{array}{l}\mathrm{VC} \\
(\%)\end{array}$ & OD & $\begin{array}{l}\mathrm{VC} \\
(\%)\end{array}$ & OD & $\begin{array}{l}\mathrm{VC} \\
(\%)\end{array}$ & OD & $\begin{array}{l}\mathrm{VC} \\
(\%)\end{array}$ \\
\hline $\mathrm{CC}$ & $\begin{array}{l}0.810 \mathrm{a} \\
(0.089)\end{array}$ & 100.0 & $\begin{array}{l}0.694 \mathrm{a} \\
(0.078)\end{array}$ & 100.0 & $\begin{array}{l}0.772 \mathrm{a} \\
(0.094)\end{array}$ & 100.0 & $\begin{array}{l}0.854 \mathrm{a} \\
(0.052)\end{array}$ & 100.0 & $\begin{array}{l}0.712 \mathrm{a} \\
(0.073)\end{array}$ & 100.0 \\
\hline C- & $\begin{array}{c}0.795 \\
(0.080)\end{array}$ & 98.2 & $\begin{array}{c}0.686 \\
(0.074)\end{array}$ & 98.9 & $\begin{array}{c}0.753 \\
(0.083)\end{array}$ & 97.6 & $\begin{array}{c}0.834 \\
(0.093)\end{array}$ & 97.7 & $\begin{array}{c}0.698 \\
(0.074)\end{array}$ & 98.1 \\
\hline $\mathrm{C}+$ & $\begin{array}{c}0.076 \\
(0.010)\end{array}$ & 9.4 & $\begin{array}{c}0.058 \\
(0.013)\end{array}$ & 8.4 & $\begin{array}{c}0.787 \\
(0.009)\end{array}$ & 10.2 & $\begin{array}{c}0.068 \\
(0.012)\end{array}$ & 8.0 & $\begin{array}{c}0.059 \\
(0.009)\end{array}$ & 8.3 \\
\hline A & $\begin{array}{l}0.739 \mathrm{~b} \\
(0.072)\end{array}$ & 91.3 & $\begin{array}{l}0.659 a \\
(0.062)\end{array}$ & 95.0 & $\begin{array}{l}0.732 b \\
(0.079)\end{array}$ & 94.9 & $\begin{array}{c}0.822 \mathrm{ba} \\
(0.08) 4\end{array}$ & 96.3 & $\begin{array}{c}0.691 \mathrm{ba} \\
(0.090)\end{array}$ & 97.1 \\
\hline $\mathrm{M}$ & $\begin{array}{l}0.616 \mathrm{c} \\
(0.069)\end{array}$ & 76.1 & $\begin{array}{l}0.560 b \\
(0.080)\end{array}$ & 80.7 & $\begin{array}{c}0.713 \mathrm{cb} \\
(0.077)\end{array}$ & 92.4 & $\begin{array}{c}0.807 \mathrm{cb} \\
(0.053)\end{array}$ & 94.6 & $\begin{array}{c}0.677 \mathrm{cb} \\
(0.061)\end{array}$ & 95.2 \\
\hline G & $\begin{array}{c}0.757 \mathrm{db} \\
(0.082)\end{array}$ & 93.5 & $\begin{array}{l}0.659 a \\
(0.071)\end{array}$ & 95.1 & $\begin{array}{c}0.727 \mathrm{dbc} \\
(0.086)\end{array}$ & 94.3 & $\begin{array}{c}0.817 \mathrm{dbc} \\
(0.070)\end{array}$ & 95.7 & $\begin{array}{c}0.689 \mathrm{dabc} \\
(0.087)\end{array}$ & 96.9 \\
\hline $\mathrm{Te}$ & $\begin{array}{c}0.651 \mathrm{ec} \\
(0.093)\end{array}$ & 80.4 & $\begin{array}{l}0.603 c \\
(0.082)\end{array}$ & 87.0 & $\begin{array}{c}0.718 \mathrm{ebcd} \\
(0.093)\end{array}$ & 93.1 & $\begin{array}{l}0.802 \mathrm{ebcd} \\
(0.069)\end{array}$ & 94.0 & $\begin{array}{c}0.676 \mathrm{ebcd} \\
(0.068)\end{array}$ & 95.0 \\
\hline $\mathrm{TP}$ & $\begin{array}{c}0.732 \mathrm{fbd} \\
(0.059)\end{array}$ & 90.4 & $\begin{array}{c}0.646 \mathrm{da} \\
(0.079)\end{array}$ & 93.1 & $\begin{array}{l}0.724 \mathrm{fbcde} \\
\quad(0.071)\end{array}$ & 93.8 & $\begin{array}{c}0.820 \text { fabcde } \\
(0.084)\end{array}$ & 96.1 & $\begin{array}{c}0.684 \text { fabcde } \\
(0.096)\end{array}$ & 96.2 \\
\hline $\mathrm{U}$ & $\begin{array}{c}0.766 \mathrm{gfbd} \\
(0.071)\end{array}$ & 94.6 & $\begin{array}{c}0.657 \mathrm{a} \\
(0.061)\end{array}$ & 94.8 & $\begin{array}{c}0.738 \text { abcdef } \\
(0.078)\end{array}$ & 95.6 & $\begin{array}{c}\text { 0.829abcdef } \\
(0.077)\end{array}$ & 97.1 & $\begin{array}{c}0.697 \text { gabcdef } \\
(0.073)\end{array}$ & 97.9 \\
\hline
\end{tabular}

$\mathrm{N}=15$. The values in the OD columns are expressed as "mean (standard deviation)". Different letters indicate statistically significant difference at 5\% (ANOVA and Tukey's test). 
$(\mathrm{p}>0.05$ ) in cell viability among Groups A, G, TP and U or between Groups $\mathrm{M}$ and Te at $24 \mathrm{~h}$ or among Groups $\mathrm{A}$, $\mathrm{M}, \mathrm{G}, \mathrm{Te}, \mathrm{TP}$ and $\mathrm{U}$ at 3 days or among Groups $\mathrm{M}, \mathrm{G}, \mathrm{Te}$, $\mathrm{TP}$ and $\mathrm{U}$ at 7 days (Table 2). No significant differences $(p>0.05)$ were observed between Groups $\mathrm{M}$ and Te in all experimental periods, except at 2 days. There were decrease viable cells in Groups $M$ and Te at 1 and 2 days compared to the other experimental periods (Table 2).

At $24 \mathrm{~h}$, the percentage of viable cells varied between $94.6 \%$ in Group U with the latex-free elastomeric ligatures, to $76.1 \%$ in Group M polyurethane elastomeric ligatures. The percentage of viable cells increased slightly over the following $24 \mathrm{~h}$ in all Groups, continued to increase in Groups M, Te, TP and U between days 2 and 28.

\section{DISCUSSION}

The cell culture model used in the present study was the monolayer (15). This model was used together with the dye-uptake technique (14) because the cytotoxicity of the materials can be determined by spectrophotometry.

Spectrophotometric assay allows rapid and reliable evidence for cell viability to be obtained based on the use of vital stain incorporated by viable cells. In this study, neutral red dye was used because it is largely employed for identification of L929 cell viability. Dead or damaged cells cannot incorporate vital stain, thus not being recognized on optical reading. Therefore, spectrophotometry does not allow dead cells to be distinguished from the damaged ones.

The choice for L929 mouse fibroblasts was due to the fact that they have results comparable to primary human gingival fibroblasts $(9,10)$, but one cannot interpret the cell culture results as a human response.

The percentage of viable cells was obtained by comparing the mean optical density (OD) of the control groups (cells with no contact with elastomeric ligatures) to that obtained from supernatants of cell cultures that had been in contacted with elastomeric ligatures.

As sterilization is a prerequisite for cytotoxicity assays, ultraviolet radiation $(12,13)$ was used in this study for $30 \mathrm{~min}$ for each elastic surface. It was observed that all elastics exhibited the same color aspect and malleability following sterilization with ultraviolet light.

Natural latex rubber has been increasingly used as a dental material, and many cytotoxicity issues have been addressed as well (5). Preservatives such as sulphur and zinc oxide as well as antioxidants such as di-thio-carbohydrates, N-nitrosodibutylamine, and $\mathrm{N}$-nitrosopiperidine are all known to be cytotoxic substances (6). Holmes et al. (16) have verified whether the colorants used in the fabrication of colored latex could have some toxic effect. Their results showed that these colorants exhibited low toxicity; but such an effect is clinically inoffensive.

The present in vitro study could not study allergic reactions to the latex-based products. Although case reports on latex allergy is not so frequently seen in the literature, allergic reactions have been relatively prevalent as latex-based products become commercially available. Most of the allergic reactions (17) have been associated with the use of orthodontic elastics (18), which is characterized by presence of small vesicles or acute edema and complaints of itching and burning.

Allergy to natural latex occurs because of the presence of many types of proteins, and the powder covering the orthodontic elastics works as a transporter for these proteins. Therefore, the development of nonlatex elastics has become increasingly important for clinical use.

In the present study, the American Orthodontics and Unitek latex-free elastomeric ligatures had less cytopathic effects than latex or polyurethane elastomeric ligatures. As the powder covering the elastomeric ligatures of all manufacturers was removed before performing the in vitro studies, it was not possible to know whether this powder would have any effect. The powder was removed in order to standardize the samples, as the composition and quantity of powder present in the elastomeric ligatures could interfere with the results.

According to Schmalz (11), the great danger is that potentially cytotoxic intraoral elastics could release substances that might be ingested by the patient over time, thus causing diseases resulting from a cumulative effect. It is known that latex is not entirely biocompatible, as it may interact with foods (4) and medications (19).

Evidence of this cytotoxic feature was shown following exposure of the elastomeric ligatures to cell culture medium. Elastomeric ligatures from Morelli, Tecnident and TP Orthodontics trademarks induced a greater amount of cell lysis at 24 and $48 \mathrm{~h}$ compared to the other experimental periods of 3, 7 and 28 days. These findings suggest a greater release of toxic ingredients within the first $48 \mathrm{~h}$ due to a possible latex or polyurethane degradation and release of cytotoxic components, which was shown on days 1 and 2, and 
did not persisted on days 3, 7 and 28 . This fact indicates that release of cytotoxic components is neither constant nor continuous. However, all elastomeric ligatures were found to be biocompatible after the 3 rd experimental day.

The polyurethane elastomeric ligature manufactured by GAC International presented better performance compared to the polyurethane elastics from Morelli and Tecnident trademarks. This suggests that different manufacturing processes of ligatures lead to different cytotoxic characteristics, despite the ligatures being made of the same type of material, polyurethane.

The latex elastomeric ligature from TP Orthodontics trademark showed better performance compared to the Morelli and Tecnident polyurethane elastomeric ligatures. Considering that latex is the main component of the TP Orthodontics ligature, it is assumed that the process of industrialization of the latex of this ligature has been done properly, minimizing any possible cytotoxic effects.

Latex-free elastomeric ligatures showed low capacity of inducing cell lysis regardless of the time evaluated.

The elastomeric ligatures evaluated in this study showed over $90 \%$ cell viability at all experimental periods, except for Morelli and Tecnident elastomeric ligatures at days 1 and 2. Hanson and Lobner (20) evaluated latex and non-latex 3/16-inch interior lumen (medium) elastics and found cell lysis to be $50 \%$ higher for latex elastics compared to non-latex ones. However, the authors considered both types of elastics appropriate for orthodontic use. Therefore, it is suggested that elastics with cell viability less than $50 \%$ should be avoided in order to prevent cumulative effects of the cytotoxic components released these elastics into the organism (11).

Further studies assessing other aspects such as the mechanism of cell lysis, can contribute to better describe in detail the cytotoxicity behavior of latex and non-latex materials. As they are widely used in clinical orthodontics, care regarding the cytotoxicity of orthodontic elastomeric ligatures should be taken as they have a very close contact with the gingiva and oral mucosas. Thus, clinically proven biocompatible materials should be acquired whenever possible.

The tested hypothesis was accepted. The latexfree elastomeric ligatures from American Orthodontics and Unitek trademarks induced a lesser amount of cell lysis compared to the latex or polyurethane elastomeric ligatures. However, latex, latex-free and polyurethane elastomeric ligatures of all manufacturers were deemed clinically biocompatible.

\section{RESUMO}

Este estudo investigou a citotoxicidade entre ligaduras elásticas ortodônticas de látex e não-látex. Seis ligaduras elásticas de diferentes fabricantes (1 látex, 2 não-látex e 3 poliuretano) foram divididos em 6 grupos de 15 elásticos cada: Grupo A (látex-free, American Orthodontics), M (Poliuretano, Morelli), G(Poliuretano, GAC International), Te (Poliuretano, Tecnident), TP (látex natural, TP Orthodontics) e U (Látex-free, 3M Unitek). $\mathrm{O}$ ensaio de citotoxicidade foi realizado utilizando culturas de células (células da linhagem L929, fibroblastos de camundongo) que foram submetidos ao teste de viabilidade celular com vermelho neutro ("dye-uptake") em 1, 2, 3, 7 e 28 dias. A análise de variância (ANOVA), com comparações múltiplas e teste de Tukey foram empregados $(\alpha=0,05)$. Os resultados mostraram que não houve diferença estatisticamente significante entre os Grupos $\mathrm{M}$ e Te em todos os tempos experimentais ( $p>0,05)$, exceto em 2 dias. Não houve diferença estatisticamente $(p>0,05)$ entre a viabilidade das células nos grupos $\mathrm{A}, \mathrm{G}, \mathrm{TP}$ e $\mathrm{U}$ ou entre os grupos $\mathrm{M}$ e Te em 24 h, ou entre os grupos CC, A, G, TP e U em 2 e 28 dias. Concluiu-se que as ligaduras elásticas látex-free das marcas American Orthodontics e Unitek induziram menor quantidade de lise celular comparado às ligaduras de látex ou poliuretano.

\section{REFERENCES}

1. Palosuo T, Alenius H, Turjanmaa K. Quantitation of latex allergens. Methods 2002;27:52-58.

2. Wakelin SH, White IR. Natural rubber latex allergy. Clin Exp Dermatol 1999;24:245-248.

3. Tomazic VJ, Withrow TJ, Fisher BR, Dillard SF. Latex-associated allergies and anaphylactic reactions. Clin Immunol Immunopathol 1992;64:89-97

4. Turjanmaa K, Alenius H, Makinen-Kiljunen S, Reunala T, Palosuo T. Natural rubber latex allergy. Allergy 1996;51:593-602.

5. Fiddler W, Pensabene J, Sphon J, Andrzejewski D. Nitrosamines in rubber bands used for orthodontic purposes. Food Chem Toxicol 1992;30:325-326.

6. Hwang CJ, Cha JY. Mechanical and biological comparison of latex and silicone rubber bands. Am J Orthod Dentofacial Orthop 2003; 124:379-386

7. Lessa FCR, Aranha AMF, Hebling J, Costa CAS. Cytotoxic effects of White- TA and MTA-Bio cements on odontoblast-like cells (MDPC-23). Braz Dent J 2010;21:24-31.

8. Miranda RB, Fidel SR, Boller MA. L929 cell response to root perforation repair cements: an in vitro cytotoxicity assay. Braz Dent J 2009;20:22-26.

9. Schedle A, Samorapoompichit P, Rausch-Fan XH, Franz A, Fureder W, Sperr WR, et al.. Response of L-929 fibroblasts, human gingival fibroblasts, and human tissue mast cells to various metal cations. J Dent Res 1995;74:1513-1520.

10. Franz A, Konig F, Skolka A, Sperr W, Bauer P, Lucas T, et al.. Cytotoxicity of resin composites as a function of interface area. Dent Mater 2007;23:1438-1446.

11. Schmalz G. Use of cell cultures for toxicity testing of dental materials - advantages and limitations. J Dent 1994;22 Suppl 2:S611.

12. Santos RL, Pithon MM, Mendes GS, Romanos MTV, Ruellas 
ACO. Cytotoxicity of intermaxillary orthodontic elastics of different colors: an in vitro study. J Appl Oral Sci 2009;4:326-329.

13. Santos RL, Pithon MM, Martins FO, Romanos MTV, Ruellas ACO. Evaluation of the cytotoxicity of latex and non-latex orthodontic separating elastics. Orthod Craniofac Res 2010;13:2833.

14. Neyndorff HC, Bartel DL, Tufaro F, Levy JG. Development of a model to demonstrate photosensitizer-mediated viral inactivation in blood. Transfusion 1990;30:485-490.

15. Tomakidi P, Koke U, Kern R, Erdinger L, Kruger H, Kohl A, et al. . Assessment of acute cyto- and genotoxicity of corrosion eluates obtained from orthodontic materials using monolayer cultures of immortalized human gingival keratinocytes. J Orofac Orthop 2000;61:2-19.

16. Holmes J, Barker MK, Walley EK, Tuncay OC. Cytotoxicity of orthodontic elastics. Am J Orthod Dentofacial Orthop 1993;104:188-191.
17. Snyder HA, Settle S. The rise in latex allergy: implications for the dentist. J Am Dent Assoc 1994;125:1089-1097.

18. Neiburger EJ. A case of possible latex allergy. J Clin Orthod 1991;25:559-560.

19. Towse A, O‘Brien M, Twarog FJ, Braimon J, Moses AC. Local reaction secondary to insulin injection. A potential role for latex antigens in insulin vials and syringes. Diabetes Care 1995; 18:1195-1197.

20. Hanson M, Lobner D. In vitro neuronal cytotoxicity of latex and nonlatex orthodontic elastics. Am J Orthod Dentofacial Orthop 2004;126:65-70. 